\title{
Enhancement of Plant Regeneration in Lemon Balm (Melissa officinalis L.) with Different Magnetic Field Applications
}

\author{
Canan Ülgen1, Arzu Birinci Yıldırım², Arzu Uçar Türker (i)1,*
}

\author{
${ }^{1}$ Department of Biology, Faculty of Science and Art, Bolu Abant Izzet Baysal University, Bolu, Turkey \\ ${ }^{2}$ Department of Field Crops, Faculty of Agricultural and Environmental Science, Bolu Abant Izzet Baysal \\ University, Bolu, Turkey
}

\begin{abstract}
Melissa officinalis L. (lemon balm) is a valuable medicinal and aromatic plant in the Lamiaceae family. Two independent experiments were performed to improve the productivity of the plant regeneration. Firstly, the most efficient in vitro culture system of $M$. officinalis was determined using 7 different explant types (leaf, petiole, stem, root, axillary buds, shoot buds and cotyledon buds) on medium containing Murashige and Skoog minimal organics (MSMO) medium with different concentrations and combinations of plant growth regulators (PGRs). Micropropagation was obtained only with explants containing meristematic cells (axillary buds, shoot tip buds and cotyledon buds). Lemon balm had a very low regeneration capacity and in the second part of the experiment, enhancement of regeneration was aimed with the applications of different magnetic fields (MFs). Two different MFs (50 and $100 \mathrm{mT}$ ) were generated using neodymium block magnets. There was no MF exposure with control treatment. Three different explants (axillary, shoot tip and cotyledon buds) were cultured on media including BA in combination with indole-3-acetic acid (IAA) or naphthalene acetic acid (NAA) with the application of two different MFs at 1 hour duration. As a result, it was determined that MF applications enhanced the regeneration capacity of $M$. officinalis and the best shoot formation was observed with axillary bud explant cultured in $1.5 \mathrm{mg} / \mathrm{L} \mathrm{BA}$ at $100 \mathrm{mT} \mathrm{MF}$ application for 1 hour duration.
\end{abstract}

\section{ARTICLE HISTORY}

Received: January 19, 2020

Revised: February 19, 2020

Accepted: March 31, 2020

\section{KEYWORDS}

In vitro culture,

Lemon balm,

Magnetic field,

Melissa officinalis,

Micropropagation

\section{INTRODUCTION}

Melissa officinalis L. (lemon balm) is an aromatic perennial plant belonging to Lamiaceae family. It has been used in the treatment of dyspepsia, irritability, insect bites, melancholy, insomnia, hysteria, depression and heart failure in folk medicine [1,2]. Strong medicinal properties of lemon balm are ascribed to the phenolic compounds such as rosmarinic acid, tannins and flavonoids [3,4]. Magnetic field (MF) applications in agriculture can be used to enhance the quality and quantity of the product [5]. Some studies reported the positive effects of various static MF intensities on seed germination, growth, regeneration and content in some plant species [6-17]. MF affects cell metabolism of meristem cells and has a crucial influence on mitosis affecting G1 phase of cell cycle [18]. MF applications increase antioxidant enzyme

CONTACT: Arzu Uçar Türker $\bowtie$ turker_a@ibu.edu.tr $\mathbf{\Xi}$ Department of Biology, Faculty of Science and Art, Bolu Abant Izzet Baysal University, Bolu, Turkey 
activities [superoxide dismutase (SOD), peroxidase (POX), catalase (CAT) and ascorbate peroxidase (APX)] and raised antioxidant activity also makes the plant more resistant to other abiotic stress factors [18].

Lemon balm is a valuable medicinal herb and according to previous studies [19-24] regeneration capacity of this plant is very low ( $\leq 5.5$ shoot). The first objective of this study was to establish an in vitro culture protocol of $M$. officinalis and secondly to improve the regeneration capacity of this plant with the application of two different MF intensities (50 mT and $100 \mathrm{mT})$.

\section{MATERIAL and METHODS}

\subsection{In vitro culture studies of $M$. officinalis}

Seeds of M. officinalis were collected from Bolu, Turkey. Identification of the plant was made by using "Flora of Turkey and the East Aegean Islands" [25]. Seeds were washed with an anti-bacterial soap, rinsed with distilled water and surface disinfested with $0.1 \%$ mercuric chloride $\left(\mathrm{HgCl}_{2}\right)$ for $15 \mathrm{~min}$ and $70 \%$ ethanol for $2 \mathrm{~min}$, and then finally rinsed with sterile water for three times. Seeds were placed in aseptic, disposable petri dishes containing Murashige and Skoog's minimal organics (MSMO) medium (4.43 g/L MSMO, Sigma Chemical Co., St. Louis, MO, USA) [26] with 30 g/L sucrose, 8 g/L Difco Bacto-agar (pH 5.7, autoclaved for 20 minutes at $121^{\circ} \mathrm{C}$ and $105 \mathrm{kPa}$ ).

For adventitious shoot formation, after six weeks incubation on germination medium, four different explants (leaf, petiole, stem and root) were excised from sterile seedlings and were cultured on MSMO medium supplemented with different combinations and concentrations of cytokinins [benzyladenine (BA), kinetin (KIN) and thidiazuron (TDZ)] and auxins [indole-3-butyric acid (IBA), indole-3-acetic acid (IAA), 2,4-dichlorophenoxyacetic acid (2,4-D) and naphthalene acetic acid (NAA)]; BA $(0.2,0.5,1.0,1.5,2.0$ and $3.0 \mathrm{mg} / \mathrm{L})+$ IAA $(0,0.2,0.5,1.0,1.5,2$ and $3.0 \mathrm{mg} / \mathrm{L})$ or NAA $(0,0.2,0.5,1.0,1.5,2$ and $3.0 \mathrm{mg} / \mathrm{L})$; BA $(0.1,0.5,1$ and $3 \mathrm{mg} / \mathrm{L})+\mathrm{IAA}(0,0.5$ and $1 \mathrm{mg} / \mathrm{L})+$ gibberellic acid $\left(\mathrm{GA}_{3} ; 0.5 \mathrm{mg} / \mathrm{L}\right) ; \mathrm{BA}(0.5$ and $1 \mathrm{mg} / \mathrm{L})+\mathrm{NAA}(0,0.5$ and $1 \mathrm{mg} / \mathrm{L})+\mathrm{GA}_{3}(0.5 \mathrm{mg} / \mathrm{L}) ; \mathrm{BA}(0.5$ and $1 \mathrm{mg} / \mathrm{L})+\mathrm{IBA}(0,0.5$ and $1 \mathrm{mg} / \mathrm{L})+\mathrm{GA}_{3}(0.5 \mathrm{mg} / \mathrm{L})$; BA $(0.1,0.5,1$ and $3 \mathrm{mg} / \mathrm{L})+\mathrm{IAA}(0,0.1,0.5$ and $1 \mathrm{mg} / \mathrm{L})+$ $\mathrm{GA}_{3}(0.5 \mathrm{mg} / \mathrm{L})+$ Ascorbic acid (AA; $\left.100 \mathrm{mg} / \mathrm{L}\right) ; 1.5 \mathrm{mg} / \mathrm{L} \mathrm{BA}+$ Chitosan $(30$ and $60 \mathrm{mg} / \mathrm{L})$; BA $(0.1,0.5,1$ and $3 \mathrm{mg} / \mathrm{L})+$ NAA $(0,0.1,0.5 \mathrm{ve} 1 \mathrm{mg} / \mathrm{L})+$ polyvinylpyrrolidone (PVP; 0.5 $\mathrm{mg} / \mathrm{L})+\mathrm{GA}_{3}(0.5 \mathrm{mg} / \mathrm{L}) ; \mathrm{KIN}(0.5,1$ and $3 \mathrm{mg} / \mathrm{L})+\mathrm{NAA}(0,0.5,1$ and $3 \mathrm{mg} / \mathrm{L})+\mathrm{GA}_{3}(0.5$ $\mathrm{mg} / \mathrm{L}) ; \mathrm{KIN}(0.5,1$ and $3 \mathrm{mg} / \mathrm{L})+\mathrm{NAA}(0,0.5,1$ and $3 \mathrm{mg} / \mathrm{L})+\mathrm{GA}_{3}(0.5 \mathrm{mg} / \mathrm{L})+\mathrm{AA}(100$ $\mathrm{mg} / \mathrm{L}) ; \mathrm{KIN}(0.5,1$ and $3 \mathrm{mg} / \mathrm{L})+\mathrm{IAA}(0,0.5,1$ and $3 \mathrm{mg} / \mathrm{L})+\mathrm{GA}_{3}(0.5 \mathrm{mg} / \mathrm{L}) ; \mathrm{KIN}(0.5,1$ and $3 \mathrm{mg} / \mathrm{L})+\mathrm{IAA}(0,0.5,1$ and $3 \mathrm{mg} / \mathrm{L})+\mathrm{GA}_{3}(0.5 \mathrm{mg} / \mathrm{L})+\mathrm{AA}(100 \mathrm{mg} / \mathrm{L}) ; \mathrm{KIN}(0.5,1$ and $3 \mathrm{mg} / \mathrm{L})+\operatorname{IBA}(0,0.5,1$ and $3 \mathrm{mg} / \mathrm{L})+\mathrm{GA}_{3}(0.5 \mathrm{mg} / \mathrm{L}) ; \mathrm{KIN}(0.5,1$ and $3 \mathrm{mg} / \mathrm{L})+\mathrm{IBA}$ $(0,0.5,1$ and $3 \mathrm{mg} / \mathrm{L})+\mathrm{GA}_{3}(0.5 \mathrm{mg} / \mathrm{L})+\mathrm{AA}(100 \mathrm{mg} / \mathrm{L}) ; \mathrm{KIN}(1,3$ and $5 \mathrm{mg} / \mathrm{L})+2,4 \mathrm{D}(1$ $\mathrm{mg} / \mathrm{L})$; Kinetin $(0.1,0.5,1$ and $3 \mathrm{mg} / \mathrm{L})+\mathrm{NAA}(0,0.1,0.5$ and $1 \mathrm{mg} / \mathrm{L})+\mathrm{PVP}(0.5 \mathrm{mg} / \mathrm{L})+$ $\mathrm{GA}_{3}(0.5 \mathrm{mg} / \mathrm{L})$; TDZ $(0.1$ and $0.5 \mathrm{mg} / \mathrm{L})+\mathrm{IAA}(0,0.5$ and $1 \mathrm{mg} / \mathrm{L})$; TDZ $(0.05,0.1,0.5$ and $1 \mathrm{mg} / \mathrm{L})+\mathrm{IAA}(0,0.5,1$ and $3 \mathrm{mg} / \mathrm{L})+\mathrm{GA}_{3}(0.5 \mathrm{mg} / \mathrm{L})$; TDZ $(0.1$ and $0.5 \mathrm{mg} / \mathrm{L})+\mathrm{NAA}(0$, $0.5,1$ and $3 \mathrm{mg} / \mathrm{L})+\mathrm{GA}_{3}(0.5 \mathrm{mg} / \mathrm{L}) ; \mathrm{TDZ}(0.1$ and $0.5 \mathrm{mg} / \mathrm{L})+2,4 \mathrm{D}(0,0.1,0.5 \mathrm{and} 1 \mathrm{mg} / \mathrm{L})$ $+\mathrm{GA}_{3}(0.5 \mathrm{mg} / \mathrm{L})$; TDZ $(0.1$ and $0.5 \mathrm{mg} / \mathrm{L})+\mathrm{IBA}(0,0.5,1$ and $3 \mathrm{mg} / \mathrm{L})+\mathrm{GA}_{3}(0.5 \mathrm{mg} / \mathrm{L})$; TDZ $(0.1$ and $0.5 \mathrm{mg} / \mathrm{L})+\mathrm{IAA}(0,0.5,1$ and $3 \mathrm{mg} / \mathrm{L})+\mathrm{GA}_{3}(0.5 \mathrm{mg} / \mathrm{L}) ; \mathrm{TDZ}(0.1,0.5$ and 1 $\mathrm{mg} / \mathrm{L})+\mathrm{IAA}(0,0.5,1$ and $3 \mathrm{mg} / \mathrm{L})+\mathrm{GA}_{3}(0.5 \mathrm{mg} / \mathrm{L})+\mathrm{AA}(100 \mathrm{mg} / \mathrm{L}) ; \mathrm{TDZ}(0.5$ and $1 \mathrm{mg} / \mathrm{L})$ + NAA $(0,0.5$ and $1 \mathrm{mg} / \mathrm{L})+$ silver nitrate $\left(\mathrm{AgNO}_{3} ; 0.25 \mathrm{mg} / \mathrm{L}\right)$; TDZ $(0.5$ and $1 \mathrm{mg} / \mathrm{L})+\mathrm{IAA}$ $(0,0.5$ and $1 \mathrm{mg} / \mathrm{L})+\mathrm{AgNO}_{3}(0.25 \mathrm{mg} / \mathrm{L}) ; \mathrm{TDZ}(0.5$ and $1 \mathrm{mg} / \mathrm{L})+\mathrm{NAA}(0,0.5$ and $1 \mathrm{mg} / \mathrm{L})$ $+\mathrm{AgNO}_{3}(0.25 \mathrm{mg} / \mathrm{L})+\mathrm{PVP}(0.5 \mathrm{mg} / \mathrm{L}) ; \mathrm{TDZ}(0.5$ and $1 \mathrm{mg} / \mathrm{L})+\mathrm{IAA}(0,0.5$ and $1 \mathrm{mg} / \mathrm{L})+$ $\mathrm{AgNO}_{3}(0.25 \mathrm{mg} / \mathrm{L})+\mathrm{PVP}(0.5 \mathrm{mg} / \mathrm{L}) ; \mathrm{TDZ}(0.1,0.5,1$ and $3 \mathrm{mg} / \mathrm{L})+\mathrm{NAA}(0,0.1,0.5$ and 1 $\mathrm{mg} / \mathrm{L})+\mathrm{PVP}(0.5 \mathrm{mg} / \mathrm{L})+\mathrm{GA}_{3}(0.5 \mathrm{mg} / \mathrm{L}) ; \mathrm{TDZ}(0.1$ and $0.5 \mathrm{mg} / \mathrm{L})+\mathrm{IAA}(0,0.5$ and $1 \mathrm{mg} / \mathrm{L})$ 
+ Chitosan (30 and $60 \mathrm{mg} / \mathrm{L}-$ after autoclaving); TDZ ( 0.1 and $0.5 \mathrm{mg} / \mathrm{L})+\mathrm{IAA}(0,0.5$ and 1 $\mathrm{mg} / \mathrm{L})+$ Chitosan (30 and $60 \mathrm{mg} / \mathrm{L}$-before autoclaving).

Half strength sucrose ( $15 \mathrm{gr} / \mathrm{L})$ and agar ( $4 \mathrm{gr} / \mathrm{L})$ were also used with above combinations. For shoot formation from preexisting meristems, three different explants (axillary buds, shoot buds and cotyledon buds) were placed in MSMO medium including BA (0.2, 0.5, 1, 1.5, 2.0 and $3 \mathrm{mg} / \mathrm{L})+$ IAA $(0.2,0.5,1.0,1.5,2$ and $3.0 \mathrm{mg} / \mathrm{L})$ or NAA $(0.2,0.5,1.0,1.5,2$ and 3.0 $\mathrm{mg} / \mathrm{L})$.

For rooting, after four weeks, all regenerated shoots were transferred to Magenta containers (GA-7 Vessel, Sigma-Aldrich ${ }^{\circledR}$ Chemical Co., St. Louis, MO, USA) containing the MS medium for an additional four weeks for shoot elongation. On the $6^{\text {th }}$ week of culture, shoot number per shooted explants and percentage of explants producing shoots were recorded. After 6 weeks, shoots were then separated individually and placed in rooting medium including MS and different concentrations of auxins (IAA; 0.5, 1, 3 and $5 \mathrm{mg} / \mathrm{L}, \mathrm{IBA} ; 0.5,1,3$ and $5 \mathrm{mg} / \mathrm{L}$, 2,4-D; 0.05, 0.5 and $1 \mathrm{mg} / \mathrm{L}$ and NAA; 0.5 and $1 \mathrm{mg} / \mathrm{L})$. Each auxin concentration had 10 replications and each experiment was repeated for three times. After 6 weeks, the number of roots and percentage of explants producing roots were recorded. After cleaning the roots of regenerated shoots with sterile distilled water, they were transferred to plastic pots containing potting soil.

\subsection{Magnetic field experiments}

Neodymium block magnets $(100 \times 50 \times 5 \mathrm{~mm})$ mounted side by side were placed in an aluminum stand. The magnetic fields $(50 \pm 5 \mathrm{mT}$ and $100 \pm 5 \mathrm{mT})$ were adjusted with magnets and a magnetic channel was formed between two magnet set to fit a $90 \mathrm{~mm}$ diameter petri plate (Figure 1). Magnetic field intensity was adjusted using Teslameter.

For magnetic field experiment, three different explants (axillary buds, shoot buds and cotyledon buds) were placed in petri plates containing $1.5 \mathrm{mg} / \mathrm{L}$ BA exposing 2 different magnetic fields (50 $\mathrm{mT}$ and $100 \mathrm{mT}$ ) at 1 hour duration and there was no MF exposure with control treatment. Explants were lined up in binary rows (3-6 explants in each row) in the middle of petri plate to obtain the uniform magnetic field intensity (Figure 1 and Figure 2a).

All cultures were incubated at $22{ }^{\circ} \mathrm{C}$ under a 16-h photoperiod (cool-white fluorescent lights, 22-28 $\mu \mathrm{mol} \mathrm{m}^{-2} \mathrm{~s}^{-1}$ ). Experiment was repeated for three times for each treatment.

\subsection{Statistical analysis}

All data were analyzed by analysis of variance (ANOVA) and mean values were compared with Duncan's Multiple Range Tests using SPSS vers. 15 (SPSS Inc, Chicago, IL, USA).

\section{RESULTS and DISCUSSION}

After many tested different concentration and combinations of PGR, it can be concluded that $M$. officinalis was very recalcitrant species for adventitious shoot formation using leaf, petiole, stem and root explants. Media supplemented with different PGR concentrations and combinations with full and half strength of MSMO and agar were not effective for adventitious shoot regeneration. Also, medium including silver nitrate, chitosan, ascorbic acid, polyvinylpyrrolidone and activated charcoal were not effective for adventitious shoot regeneration. 
Table 1. Regeneration of axillary buds in magnetic fields (50 $\mathrm{mT}$ and $100 \mathrm{mT})$ and without magnetic field exposure (control) in media containing different PGR combinations.

\begin{tabular}{|c|c|c|c|c|c|c|}
\hline \multirow[b]{3}{*}{ PGRs (mg/L) } & \multicolumn{6}{|c|}{ Axillary bud } \\
\hline & \multicolumn{3}{|c|}{ Mean number of shoots $( \pm \mathrm{SE})$} & \multicolumn{3}{|c|}{$\%$ explants forming shoots } \\
\hline & $50 \mathrm{mT}$ & $100 \mathrm{mT}$ & Control & $50 \mathrm{mT}$ & $100 \mathrm{mT}$ & Control \\
\hline$\underline{\text { PGR free }}$ & $0.6 \pm 0.5^{\mathrm{d}}$ & $0.6 \pm 1.1^{\mathrm{c}}$ & $0.3 \pm 0.6^{\mathrm{c}}$ & 33 & 33 & 33 \\
\hline \multicolumn{7}{|l|}{$\underline{\mathrm{BA}}$} \\
\hline 0.2 & $2.75 \pm 2.2^{\mathrm{d}}$ & - & - & 55 & - & - \\
\hline 0.5 & $4.25 \pm 3.3^{\mathrm{c}}$ & - & - & 20 & - & - \\
\hline 1.0 & $1.75 \pm 1.0^{\mathrm{d}}$ & - & - & 35 & - & - \\
\hline 1.5 & $9.5 \pm 1.3^{\mathrm{a}}$ & $12.5 \pm 2.1^{\mathrm{a}}$ & $8.3 \pm 2.5^{\mathrm{a}}$ & 70 & 75 & 65 \\
\hline 2.0 & - & - & - & - & - & - \\
\hline 3.0 & - & - & - & - & - & - \\
\hline \multicolumn{7}{|l|}{$\underline{\mathrm{BA}}+\mathrm{NAA}$} \\
\hline $0.2+0.2$ & - & - & - & - & - & - \\
\hline $0.5+0.5$ & - & - & $3.5 \pm 1.8^{b}$ & - & - & 35 \\
\hline $1.0+1.0$ & - & - & - & - & - & - \\
\hline $1.5+1.5$ & - & - & - & - & - & - \\
\hline $2.0+2.0$ & - & - & - & - & - & - \\
\hline $3.0+3.0$ & - & $9.5 \pm 1.3^{\mathrm{b}}$ & - & - & 60 & - \\
\hline \multicolumn{7}{|l|}{$\underline{\mathrm{BA}}+\mathrm{IAA}$} \\
\hline $0.2+0.2$ & $6.3 \pm 2.6^{\mathrm{a}}$ & - & $2.3 \pm 1.3^{\mathrm{b}}$ & 100 & - & 50 \\
\hline $0.5+0.5$ & - & - & - & - & - & - \\
\hline $1.0+1.0$ & - & - & - & - & - & - \\
\hline $1.5+1.5$ & - & - & - & - & - & - \\
\hline $2.0+2.0$ & - & - & - & - & - & - \\
\hline $3.0+3.0$ & - & - & - & - & - & - \\
\hline
\end{tabular}

*Data presented as mean number of shoots per explant \pm standard error (SE). ${ }^{\text {a,b,c,d }}$ Mean values with the same letters within vertical columns are not significantly different $(p>0.05)$ (i.e., Comparison of PGR combinations for each explant and MF applications).

Only explants having preexisting meristem were successful for shoot regeneration. Shoot multiplication via meristem proliferation was obtained with explants containing meristematic cells (axillary buds, shoot buds and cotyledon buds). Among control treatments (no MF applications), best shoot proliferation was obtained with axillary bud at $1.5 \mathrm{mg} / \mathrm{L} \mathrm{BA}(8.3 \pm 2.5$ shoots per explant at $65 \%$ shoot frequency). Hypocotyl bud was also efficient for shoot regeneration at $0.5 \mathrm{BA}+0.5 \mathrm{NAA}$ combination $(6.8 \pm 2.2$ shoots per explant at $75 \%$ shoot frequency) (Table 1, Table 2 and Table 3). Low regeneration efficiency of $M$. officinalis was reported with previous studies via meristem proliferation [19-24]. Tavares et al. [19] reported multiple shoot formation from cotyledonary node explants of 10-day-old $M$. officinalis. The highest average number of shoots was obtained with $2 \mathrm{mg} / \mathrm{L}$ of BA (4 shoots). Meszaros et al. [20] developed a micropropagation technique which is applicable for field cultivated plants for M. officinalis using shoot tips. The combination of $1 \mathrm{mg} / \mathrm{L} \mathrm{IAA}$ and $1.5 \mathrm{mg} / \mathrm{L} \mathrm{BA}$ resulted in the best multiplication (5.5 shoots). Tantos et al. [21] investigated the effect of triacontanol supplemented with $1 \mathrm{mg} / \mathrm{L} \mathrm{BA}$ and $0.5 \mathrm{mg} / \mathrm{L}$ IAA on micropropagation of lemon balm using shoot tips. They obtained less than 3 shoots with triacontanol free medium with $1 \mathrm{mg} / \mathrm{L} \mathrm{BA}$ and $0.5 \mathrm{mg} / \mathrm{L}$ IAA. Addition of triacontanol was not effective to increase the shoot number $(<5.5$ shoots). Silva et al. [22] reported that nodal segments of M. officinalis cultured on $2 \mathrm{mg} / \mathrm{L}$ BA 
produced 2.57 shoots. Meftahizade et al. [23] investigated the optimization of micropropagation in M. officinalis. They tried different concentrations of alone BA or BA with combinations of IAA, IBA or NAA. But shoot number was less than 5 shoots with all of the treatment. Statistical analysis of their results showed that $3 \mathrm{mg} / \mathrm{L} \mathrm{BA}$ in combination with $1 \mathrm{mg} / \mathrm{L} \mathrm{NAA}$ had the highest regeneration in shoot tips explants (5 shoots).

Table 2. Regeneration of shoot tip buds in magnetic fields (50 $\mathrm{mT}$ and $100 \mathrm{mT})$ and without magnetic field exposure (control) in media containing different PGR combinations.

\begin{tabular}{|c|c|c|c|c|c|c|}
\hline \multirow[b]{3}{*}{ PGRs $(\mathrm{mg} / \mathrm{L})$} & \multicolumn{6}{|c|}{ Shoot tip bud } \\
\hline & \multicolumn{3}{|c|}{ Mean number of shoots $( \pm$ SE $)$} & \multicolumn{3}{|c|}{$\%$ explants forming shoots } \\
\hline & $50 \mathrm{mT}$ & $100 \mathrm{mT}$ & Control & $50 \mathrm{mT}$ & $100 \mathrm{mT}$ & Control \\
\hline$\underline{\text { PGR free }}$ & $1.0 \pm 1.0^{\mathrm{d}}$ & $0.6 \pm 0.5^{\mathrm{e}}$ & $0.3 \pm 0.6^{\mathrm{c}}$ & 33 & 33 & 66 \\
\hline \multicolumn{7}{|l|}{$\underline{\mathrm{BA}}$} \\
\hline 0.2 & - & $7.25 \pm 3.2^{\mathrm{ab}}$ & - & - & 25 & - \\
\hline 0.5 & - & $6.3 \pm 1.3^{\mathrm{b}}$ & - & - & 40 & - \\
\hline 1.0 & - & - & - & - & - & - \\
\hline 1.5 & $3.5 \pm 1.7^{\mathrm{b}}$ & $8.5 \pm 2.1^{\mathrm{a}}$ & $3.3 \pm 1.5^{\mathrm{b}}$ & 50 & 80 & 66 \\
\hline 2.0 & $1.8 \pm 1.5^{\mathrm{d}}$ & $6.0 \pm 2.2^{\mathrm{b}}$ & - & 33 & 33 & - \\
\hline 3.0 & - & - & - & - & - & - \\
\hline \multicolumn{7}{|l|}{$\underline{\mathrm{BA}}+\mathrm{NAA}$} \\
\hline $0.2+0.2$ & $2.8 \pm 1.5^{\mathrm{c}}$ & $7.3 \pm 2.6^{\mathrm{ab}}$ & - & 50 & 60 & - \\
\hline $0.5+0.5$ & $1.5 \pm 1.3^{\mathrm{d}}$ & $4.8 \pm 2.2^{\mathrm{c}}$ & $3.8 \pm 1.9^{b}$ & 50 & 55 & 45 \\
\hline $1.0+1.0$ & - & - & - & - & - & - \\
\hline $1.5+1.5$ & - & - & - & - & - & - \\
\hline $2.0+2.0$ & - & - & - & - & - & - \\
\hline $3.0+3.0$ & - & $3.3 \pm 1.7^{\mathrm{d}}$ & - & - & 30 & - \\
\hline \multicolumn{7}{|l|}{$\underline{\mathrm{BA}}+\mathrm{IAA}$} \\
\hline $0.2+0.2$ & $5.3 \pm 1.0^{\mathrm{b}}$ & - & $6.3 \pm 1.5^{\mathrm{a}}$ & 60 & - & 30 \\
\hline $0.5+0.5$ & - & - & - & - & - & - \\
\hline $1.0+1.0$ & - & - & - & - & - & - \\
\hline $1.5+1.5$ & - & - & - & - & - & - \\
\hline $2.0+2.0$ & - & - & - & - & - & - \\
\hline $3.0+3.0$ & - & $7.25 \pm 3.3^{\mathrm{ab}}$ & - & - & 70 & - \\
\hline
\end{tabular}

${ }^{*}$ Data presented as mean number of shoots per explant \pm standard error (SE). ${ }^{\text {a,b,c,d }}$ Mean values with the same letters within vertical columns are not significantly different $(p>0.05)$ (i.e., Comparison of PGR combinations for each explant and MF applications).

Mohebalipour et al. [24] evaluated the regeneration capacity of different landraces of nodal segments of $M$. officinalis on MS medium containing $2 \mathrm{mg} / \mathrm{L} \mathrm{BA}$ alone or in combination with $2 \mathrm{mg} / \mathrm{L}$ IAA. Maximum average shoot number (4.97 shoots) was observed with $2 \mathrm{mg} / \mathrm{L}$ BA. Regenerated shoots were cultured on shoot elongation medium containing MSMO for additional 4 weeks. After 2 weeks, regenerated shoots were separated individually and cultured on MSMO medium including IAA, IBA, 2.4-D or NAA. Regenerated shoots were rooted in basal MS medium (control) (Figure 2c). The best root formation was obtained with basal medium or $0.5 \mathrm{mg} / \mathrm{L}$ IAA regarding the root number and root formation frequency (Table 4). Although 0.5 or $1 \mathrm{mg} / \mathrm{L}$ IAA caused root formation, increasing concentrations of IAA $(3 \mathrm{mg} / \mathrm{L})$ seriously inhibited root development. IBA and NAA concentrations were not productive for root formation, and root induction was not occurred with all tested concentrations of 2,4-D. The rooted plants were transferred to plastic pots containing sterile soil and kept in growth room 
conditions at $22{ }^{\circ} \mathrm{C}$ under a 16-h photoperiod (Figure 2d). The rooted plants had $80 \%$ survival rate through the hardening off process. Similar to our result, Tavares et al. [19] showed that roots were developed in MS medium alone or supplemented with IBA or NAA. Meszaros et al. [20] also observed root development with PGR free medium. Meftahizade et al. [23] obtained the best root formation (3.2 roots) with $1 \mathrm{mg} / \mathrm{L}$ NAA. On the other hand, 7.75 roots were obtained with $1 \mathrm{mg} / \mathrm{L}$ NAA in our study (Table 4).

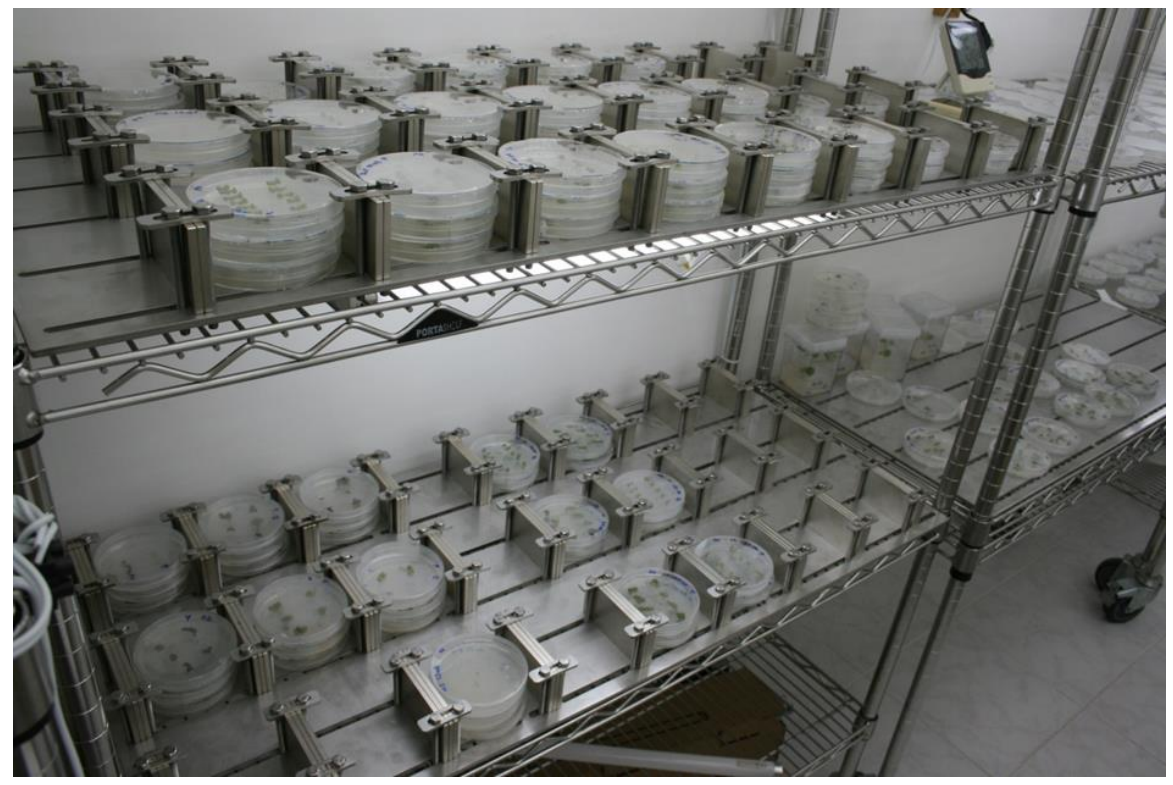

Figure 1. Magnetic field setup-50 mT (above), $100 \mathrm{mT}$ (below left) and control (MF free) (below right).

In the second part of the experiment, explants having preexisting meristem (axillary buds, shoot buds and cotyledon buds) were used for MF applications. Explants were cultured on MSMO medium including BA in combination with IAA or NAA at $50 \mathrm{mT}$ or $100 \mathrm{mT}$ for 1 hour duration (Table 1, Table 2 and Table 3). No MF was also applied as control and regeneration efficiency of 3 explants were compared [50 mT, $100 \mathrm{mT}$ and control]. One hour MF exposure was chosen for this experiment in regarding to the result of our previous study [17]. Ulgen et al. [17] reported that exposure time of MF was a significant factor for lemon balm seed germination and low duration (1 hour) gave the best germination rate. Explant was also cultured on media including no PGR was also tested for shoot regeneration capacity exposing $50 \mathrm{mT}$ or $100 \mathrm{mT}$ MF applications. Only MF applications without PGR were not effective for shoot regeneration. Very low shoot regeneration capacity was observed without PGRs (0.3 to 1 shoots) (Table 1, Table 2 and Table 3 ).

Regeneration capacity of lemon balm was improved with two different MF applications $(50 \mathrm{mT}$ and $100 \mathrm{mT})$ at 1 hour duration. The best shoot development was obtained with axillary bud cultured on MSMO medium suplemented with $1.5 \mathrm{mg} / \mathrm{L} \mathrm{BA}$ exposed to $100 \mathrm{mT}$ MF (12.5 \pm 2.1 shoots per explant at $75 \%$ shoot frequency) (Table 1, Table 2 and Table 3) (Figure $2 \mathrm{a}$ and $\mathrm{b}$ ). Shoot regeneration showed 50.6\% increase with $100 \mathrm{mT}$ MF application (from 8.3 shoots to 12.5 shoots per explant) (Table 1). Explants (shoot tip and hypocotyl buds) exposed to100 mT MF also showed increased number of shoot regeneration (from 3.3 to 8.5 shoots for shoot tip bud explant and from 2.8 to 9.3 shoots for hypocotyl bud explant). Shoot frequency (\% explants forming shoots) was also improved with $100 \mathrm{mT} \mathrm{MF}$ application for axillary bud and shoot tip explants (from $65 \%$ to $75 \%$ for axillary bud and from $66 \%$ to $80 \%$ for shoot tip bud explants) (Table 1, Table 2 and Table 3 ).

Several studies showed that MF aplications considerably affect the cell metabolism and mitosis in plant meristematic cells [27]. Many studies with different plant species reported the 
positive effect of low MF applications on plant growh, regeneration rate, shoot and root number, plant fresh and dry weight, leaf number and stem length $[5,18,28]$. Similar to our findings, MF application improved the regeneration capability of Paulownia tomentosa (Thunb.) Steud. and P. fortunei (Seem.) Hemsl. node explants cultured on MS medium supplemented with $1 \mathrm{mg} / \mathrm{L}$ BA+0.1 mg/L NAA [27]. Regeneration capacity of soybean shoot tip explants cultured on Gamborg's medium and vitamins supplemented with $40 \mathrm{mg} / \mathrm{L}$ adenine sulfate $+0.1 \mathrm{~g} / \mathrm{L}$ glutamine $+0.1 \mathrm{mg} / \mathrm{L} 2,4-\mathrm{D}$ was also improved with MF applications [29].

Table 3. Regeneration of hypocotyls buds in magnetic fields (50 mT and $100 \mathrm{mT}$ ) and without magnetic field exposure (control) in media containing different PGR combinations.

\begin{tabular}{|c|c|c|c|c|c|c|}
\hline \multirow[b]{3}{*}{ PGRs (mg/L) } & \multicolumn{6}{|c|}{ Hypocotyl bud } \\
\hline & \multicolumn{3}{|c|}{ Mean number of shoots $( \pm \mathrm{SE})$} & \multicolumn{3}{|c|}{$\%$ explants forming shoots } \\
\hline & $50 \mathrm{mT}$ & $100 \mathrm{mT}$ & Control & $50 \mathrm{mT}$ & $100 \mathrm{mT}$ & $\begin{array}{c}\text { Contro } \\
1\end{array}$ \\
\hline PGR free & $1.0 \pm 0.6^{\mathrm{d}}$ & $0.3 \pm 0.5^{\mathrm{c}}$ & - & 66 & 33 & - \\
\hline \multicolumn{7}{|l|}{ BA } \\
\hline 0.2 & - & - & - & - & - & - \\
\hline 0.5 & $2.0 \pm 0.8^{\mathrm{d}}$ & - & - & 25 & - & - \\
\hline 1.0 & $5.3 \pm 0.9^{b}$ & - & - & 40 & - & - \\
\hline 1.5 & $8.0 \pm 0.8^{\mathrm{a}}$ & $9.3 \pm 1.5^{\mathrm{a}}$ & $2.8 \pm 0.5^{\mathrm{c}}$ & 80 & 50 & 75 \\
\hline 2.0 & - & - & - & - & - & - \\
\hline 3.0 & $3.8 \pm 1.7^{\mathrm{c}}$ & - & - & 25 & - & - \\
\hline \multicolumn{7}{|l|}{$\underline{\mathrm{BA}}+\mathrm{NAA}$} \\
\hline $0.2+0.2$ & - & - & - & - & - & - \\
\hline $0.5+0.5$ & - & - & $6.8 \pm 2.2^{\mathrm{a}}$ & - & - & 75 \\
\hline $1.0+1.0$ & - & - & - & - & - & - \\
\hline $1.5+1.5$ & - & - & - & - & - & - \\
\hline $2.0+2.0$ & - & - & - & - & - & - \\
\hline $3.0+3.0$ & $3.3 \pm 1.5^{\mathrm{c}}$ & $4.3 \pm 0.9^{b}$ & - & 50 & 40 & - \\
\hline \multicolumn{7}{|l|}{$\underline{\mathrm{BA}}+\mathrm{IAA}$} \\
\hline $0.2+0.2$ & $4.8 \pm 2.2^{\mathrm{bc}}$ & - & $5.5 \pm 2.4^{\mathrm{b}}$ & 65 & - & 50 \\
\hline $0.5+0.5$ & - & - & - & - & - & - \\
\hline $1.0+1.0$ & - & - & - & - & - & - \\
\hline $1.5+1.5$ & - & - & - & - & - & - \\
\hline $2.0+2.0$ & - & - & - & - & - & - \\
\hline $3.0+3.0$ & - & - & - & - & - & - \\
\hline
\end{tabular}

*Data presented as mean number of shoots per explant \pm standard error (SE). ${ }^{\text {a,b,c,d }}$ Mean values with the same letters within vertical columns are not significantly different $(p>0.05)$ (i.e., Comparison of PGR combinations for each explant and MF applications).

Racuciu et al. [29] demonstrated an increase in chlorophyll, carotenoid and nucleic acid levels in Zea mays L. with low static MF application (50 mT). Reina and Pascual [7] showed that lettuce seeds exposed to a stationary magnetic field increased water uptake. Applied MF altered in intracellular levels of $\mathrm{Ca}^{2+}$ and other ionic current density across cellular membrane. This shift caused changes in osmotic pressure and the capacity of cellular tissues to absorb water. Saktheeswari and Subrahmanyam [30] investigated the effects of pulsed magnetic field on Oryza sativa L. and inferred that the ion-cyclotron resonance might have interfered with the $\mathrm{Ca}^{2+}$ ion sequestering and thereby allowed a rise in free $\mathrm{Ca}^{2+}$ concentration in the system that 
might be a signal to the cell to enter into early mitotic cycle. Enhanced regeneration capability of M. officinalis explant exposed to MFs may be related to increased uptake of $\mathrm{Ca}^{2+}$ ions.

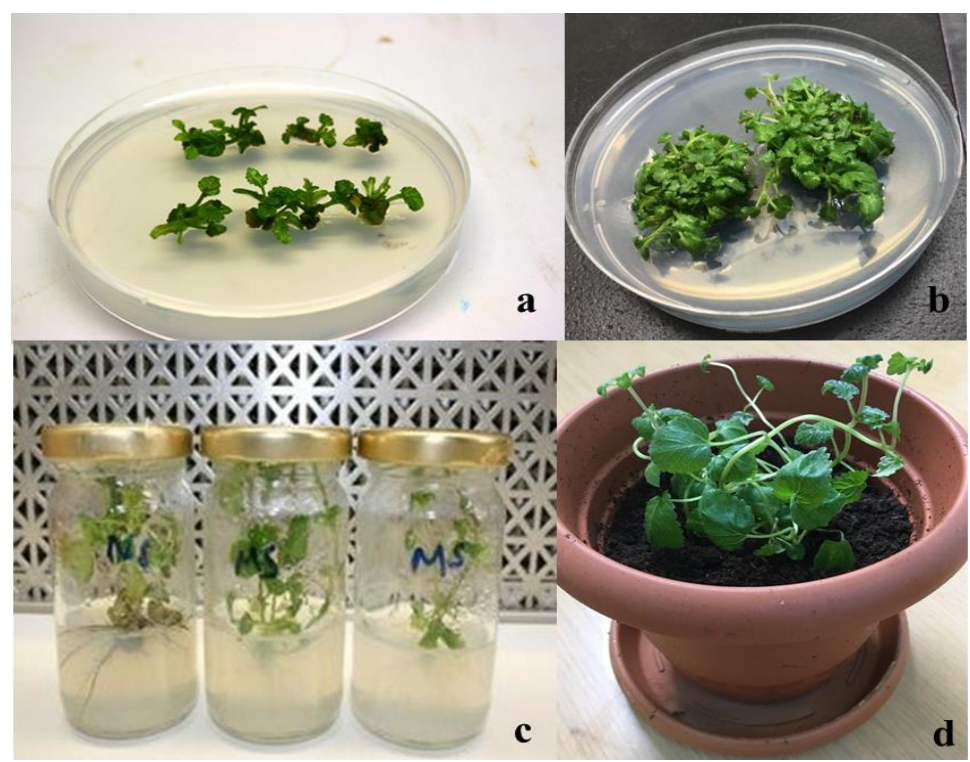

Figure 2. In vitro regeneration of M. officinalis: a) Axillary bud explants lined up in binary rows for MF application, b) Shoot regeneration from axillary bud explants cultured on MSMO medium containing $1.5 \mathrm{mg} / \mathrm{L} \mathrm{BA}$, with $100 \mathrm{mT}$ MF application,c) Rooting of the regenerated shoots on MS basal medium, d) Regenerated plant under growth room conditions

Table 4. Effects of IAA, IBA, 2,4-D and NAA on root formation from regenerated shoots.

\begin{tabular}{|c|c|c|}
\hline Auxins (mg/L) & Mean number of roots $( \pm$ SE) & $\%$ explants forming roots \\
\hline Control & $12.25 \pm 1.3^{\mathrm{a}}$ & 100 \\
\hline \multicolumn{3}{|l|}{$\underline{\text { IAA }}$} \\
\hline 0.5 & $11 \pm 2.5^{\mathrm{a}}$ & 100 \\
\hline 1.0 & $10 \pm 2.1^{\mathrm{ab}}$ & 100 \\
\hline 3.0 & - & - \\
\hline \multicolumn{3}{|l|}{$\underline{\text { IBA }}$} \\
\hline 0.5 & $6.5 \pm 2.4^{\mathrm{bc}}$ & 75 \\
\hline 1.0 & $8 \pm 2.0^{\mathrm{b}}$ & 75 \\
\hline 3.0 & $4.25 \pm 2.5^{\mathrm{c}}$ & 50 \\
\hline \multicolumn{3}{|l|}{$\underline{\mathrm{NAA}}$} \\
\hline 0.5 & - & - \\
\hline 1.0 & $7.75 \pm 2.6^{\mathrm{b}}$ & 75 \\
\hline 3.0 & - & - \\
\hline \multicolumn{3}{|l|}{$2,4-\mathrm{D}$} \\
\hline 0.1 & - & - \\
\hline 0.5 & - & - \\
\hline 1.0 & - & - \\
\hline
\end{tabular}

${ }^{*}$ Data presented as mean number of roots per explant \pm standard error (SE). Means with the same letter within columns are not significantly different at $p>0.05$. Control means no auxin added to the media. ${ }^{\mathrm{a}, \mathrm{b}, \mathrm{c}}$ Mean values with the same letters within vertical columns are not significantly different $(p>0.05)$ 


\section{CONCLUSION}

An efficient in vitro regeneration system was developed for $M$. officinalis via explants containing preexisting meristems (axillary buds, shoot tip buds and cotyledon buds) and then regeneration efficiency was enhanced with 2 different MF applications (50 mT and $100 \mathrm{mT}$ ). Especially axillary bud explant exposed to $100 \mathrm{mT}$ MF for 1 hour improved the regeneration capacity of $M$. officinalis. Medicinal value of $M$. officinalis propagated with different magnetic field applications should be investigated making comparison in terms of phenolic content (especially rosmarinic acid), antioxidant potential and antioxidant enzymes in future studies.

\section{Acknowledgements}

This study was supported by the Abant Izzet Baysal University Research Foundation (BAP 2016.03.01.1027). We are grateful to Dr. Asaf Tolga Ülgen for his technical supports.

\section{Declaration of Conflicting Interests and Ethics}

The authors declare no conflict of interest. This research study complies with research publishing ethics. The scientific and legal responsibility for manuscripts published in IJSM belongs to the author(s).

\section{Orcid}

Arzu Ucar Turker (iD https://orcid.org/0000-0001-9617-6673

\section{REFERENCES}

[1]. Chevallier, A. (1996). The encyclopedia of medicinal plants; Dorling Kindersley, London.

[2]. Moradkhani, H., Sargsyan E., Bibak H., Naseri B., Sadat-Hosseini M., Fayazi-Barjin A., Meftahizade H. (2010). Melissa officinalis L., a valuable medicine plant: A review. J. Med. Plants Res., 4, 2753-2759.

[3]. Petersen, M., Simmonds, M.S. (2003). Rosmarinic acid. Phytochem., 62, 121-125.

[4]. Barros, L., Dueñas, M., Dias, M.I., Sousa, M.J., Santos-Buelga, C., Ferreira, I.C. (2013). Phenolic profiles of cultivated, in vitro cultured and commercial samples of Melissa officinalis L. infusions. Food Chem., 136, 1-8.

[5]. Racuciu, M., Creanga, D., Horga, I. (2008). Plant growth under static magnetic field influence. Rom. J. Phys., 53, 353-359.

[6]. Hirota, N., Nakagawa J., Kitazawa, K. (1999). Effects of a magnetic field on the germination of plants. J. App. Phys., 85, 5717-5719.

[7]. Reina, F.G., Pascual, L.A. (2001). Influence of a stationary magnetic field on water relations in lettuce seeds. Part I: theoretical considerations. Bioelectromagnetics, 22, 589595.

[8]. Ruzic, R., Jerman, I. (2002). Weak magnetic field decreases heat stress in cress seedlings. Electromagn. Biol. Med., 21, 69-80.

[9]. Ghanati, F., Abdolmaleki, P., Vaezzadeh, M., Rajabbeigi, E., Yazdani, M. (2007). Application of magnetic field and iron in order to change medicinal products of Ocimum basilicum. The Environmentalist, 27, 429-434.

[10]. Racuciu, M. (2012). Influence of extremely low frequency magnetic field on assimilatory pigments and nucleic acids in Zea mays and Curcubita pepo seedlings. Rom. Biotech. Lett., 17, 7663.

[11]. Aladjadjiyan, A. (2010). Influence of stationary magnetic field on lentil seeds. Int. Agrophys., 24, 321-324.

[12]. Yalçın, S., Tayyar, Ş. (2011). Oğulotu tohumlarının çimlenmesi ve fide gelişimi üzerine manyetik alanın etkisi. Yüzüncü Yll Üniversitesi Tarım Bilimleri Dergisi., 21, 190-197. 
[13]. Florez, M., Martínez, E., Carbonell, M.V. (2012). Effect of magnetic field treatment on germination of medicinal plants Salvia officinalis L. and Calendula officinalis L. Pol. $J$. Environ. Stu., 21, 57-63.

[14]. Kuzugüdenli, E., Canpolat, K. (2012). Karaçamın (Pinus nigra Arnold.) Çimlenmesi Ve Gelişimi Üzerine Manyetik Alanın Etkisi. Biyoloji Bilimleri Araştırma Dergisi, 2, 31-34.

[15]. Subber, A.R., Hail, R.C.A., Jabail, W.A., Hussein, H.F. (2012). Effects of magnetic field on the growth development of Zea mays seeds. J. Nat. Prod. Plant Resour., 2, 456-459.

[16]. Sen, A., Alikamanoglu, S. (2014). Effects of static magnetic field pretreatment with and without PEG 6000 or $\mathrm{NaCl}$ exposure on wheat biochemical parameters. Russ. J. of Plant Physiol., 61, 646-655.

[17]. Ulgen, C., Yildırım, A.B., Turker, A.U. (2017). Effect of magnetic field treatments on seed germination of Melissa officinalis L. Int. J. Second. Metab., 4, 43-49.

[18]. Alikamanoglu, S., Sen, A. (2011). Stimulation of growth and some biochemical parameters by magnetic field in wheat (Triticum aestivum L.) tissue cultures. Afr. J. Biotechnol., 10, 10957-10963.

[19]. Tavares, A.C., Pimento, M.C., Goncalves, M.T. (1996). Micropropagation of Melissa officinalis L. through proliferation of axillary shoots. Plant Cell Rep., 15, 441-444.

[20]. Meszaros, A., Bellon Pinter, E., Horvath, G. (1999). Micropropagation of lemon balm, Plant Cell Tiss. Org., 57, 149-152

[21]. Tantos, A., Mészáros, A., Kissimon, J., Horváth, G., Farkas, T. (1999). The effect of triacontanol on micropropagation of balm, Melissa officinalis L. Plant Cell Rep., 19, 8891.

[22]. Silva, S.D., Sato, A., Lage, C.L.S., Gil, S., da Silva, R.A., Azevedo, D.D.A., Esquibel, M.A. (2005). Essential oil composition of Melissa officinalis L. in vitro produced under the influence of growth regulators. J. Braz. Chem. Soc., 16, 1387-1390.

[23]. Meftahizade, H., Lotfi, M., Moradkhani, H. (2010). Optimization of micropropagation and establishment of cell suspension culture in Melissa officinalis L. Afr. J. Biotechnol., 9, 4314-4321.

[24]. Mohebalipour, N., Aharizad, S., Mohammadi, S., Motallebiazar, A., Arefi, H. (2012). Effect of plant growth regulators BAP and IAA on micropropagation of Iranian lemon balm (Melissa officinalis L.) landraces. J. Food Agr. Environ., 10, 280-286.

[25]. Davis, P.H. (1982). Flora of Turkey and the East Aegean Islands; Edinburgh University Press, Edinburgh.

[26]. Murashige T., Skoog, F. (1962). A revised medium for rapid growth and bioassays with tobacco tissue culture. Physiol. Plantarum., 15, 473-497.

[27]. Yaycili, O., Alikamanoglu, S. (2005). The effect of magnetic field on Paulownia tissue cultures. Plant Cell Tiss Org., 83, 109-114.

[28]. Lucchesini, M., Sabatini, A.M., Vitagliano, C., Dario, P. (1992). The pulsed electromagnetic field stimulation effect on development of Prunus cerasifera in vitro-derived plantlets. Int. Symp. on Transplant Produc. Sys., 319, 131-136.

[29]. Atak, Ç., Emiroğlu, Ö., Alikamanoğlu, S., Rzakoulieva, A. (2003). Stimulation of regeneration by magnetic field in soybean (Glycine $\max$ L. Merrill) tissue cultures. J. Cell Mol. Biol., 2, 113-119.

[30]. Saktheeswari, N., Subrahmanyam, S. (1989). Effects of pulsed magnetic field on histology, biochemistry and magnetotropism of paddy (Oryza sativa). Bioelectromagn. Biomed., 2, 37-44. 